\title{
Anlotinib as a third-line therapy in patients with refractory advanced non-small-cell lung cancer: a multicentre, randomised phase II trial (ALTER0302)
}

Baohui Han*,1, ${ }^{*}$, Kai Li ${ }^{2,14}$, Yizhuo Zhao ${ }^{1}$, Baolan Li ${ }^{3}$, Ying Cheng ${ }^{4}$, Jianying Zhou ${ }^{5}$, You Lu ${ }^{6}$, Yuankai Shi ${ }^{7}$, Zhehai Wang $^{8}$, Liyan Jiang ${ }^{1}$, Yi Luo ${ }^{9}$, Yiping Zhang ${ }^{10}$, Cheng Huang ${ }^{11}$, Qiang Li $^{12}$ and Guoming Wu ${ }^{13}$

${ }^{1}$ Shanghai Chest Hospital, Shanghai Jiaotong University, Shanghai 230030, China; ${ }^{2}$ Tianjin Medical University Cancer Hospital, Tianjin 300040, China; ${ }^{3}$ Beijing Chest Hospital, Capital Medical University, Beijing 101149, China; ${ }^{4} \mathrm{Jilin}$ Province Tumor Hospital, Changchun 130012, China; ${ }^{5}$ The First Affiliated Hospital, Medical School of Zhejiang University, Hangzhou 310009, China; ${ }^{6}$ West China Hospital, Sichuan University, Chengdu 610041, China; ${ }^{7}$ Cancer Institute and Hospital, Chinese Academy of Medical Sciences, Beijing 100021, China; ${ }^{8}$ Shandong Cancer Hospital, Jinan 250117, China; ${ }^{9}$ Hunan Cancer Hospital, Changsha 220633, China; ${ }^{10}$ Zhejiang Cancer Hospital, Hangzhou 310022, China; ${ }^{11}$ Fujian Cancer Hospital, Fuzhou 350001, China; ${ }^{12}$ Changhai Hospital, Second Military Medical University, Shanghai 200433, China and ${ }^{13}$ The Second Affiliated Hospital, Third Military Medical University, Chongqing 400037, China

Background: Anlotinib (AL3818) is a novel multitarget tyrosine kinase inhibitor, inhibiting tumour angiogenesis and proliferative signalling. The objective of this study was to assess the safety and efficacy of third-line anlotinib for patients with refractory advanced non-small-cell lung cancer (RA-NSCLC).

Methods: Eligible patients were randomised 1:1 to receive anlotinib (12 mg per day, per os; days 1-14; 21 days per cycle) or a placebo. The primary end point was progression-free survival (PFS).

Results: A total of 117 eligible patients enrolled from 13 clinical centres in China were analysed in the full analysis set. No patients received immune check-point inhibitors and epidermal growth factor receptor status was unknown in $60.7 \%$ of the population. PFS was better with anlotinib compared with the placebo (4.8 vs 1.2 months; hazard ratio $(\mathrm{HR})=0.32 ; 95 \%$ confidence interval $(\mathrm{Cl})$, $0.20-0.51 ; P<0.0001)$, as well as overall response rate (ORR) $(10.0 \%$; $95 \% \mathrm{Cl}, 2.4-17.6 \%$ vs $0 \% ; 95 \% \mathrm{Cl}, 0-6.27 \% ; P=0.028)$. The median overall survival (OS) was 9.3 months $(95 \% \mathrm{Cl}, 6.8-15.1)$ for the anlotinib group and 6.3 months $(95 \% \mathrm{Cl}, 4.3-10.5)$ for the placebo group $(\mathrm{HR}=0.78 ; 95 \% \mathrm{Cl}, 0.51-1.18 ; P=0.2316)$. Adverse events were more frequent in the anlotinib than the placebo group. The percentage of grade 3-4 treatment-related adverse events was $21.67 \%$ in the anlotinib group.

Conclusions: Anlotinib as a third-line treatment provided significant PFS benefits to patients with RA-NSCLC when compared with the placebo, and the toxicity profiles showed good tolerance.

\footnotetext{
*Correspondence: Professor B Han; E-mail: 18930858216@163.com

${ }^{14}$ These authors contributed equally to this work.
}

Received 21 June 2017; revised 3 December 2017; accepted 4 December 2017; published online 13 February 2018

(C) 2018 Cancer Research UK. All rights reserved 0007-0920/18 
Lung cancer is the leading cause of worldwide cancer mortality (Torre et al, 2015). Non-small-cell lung cancer (NSCLC) accounts for $\sim 85 \%$ of all lung cancers (Molina et al, 2008). Most lung cancer cases are diagnosed in the advanced stages, and only a minority of these patients can be treated with surgery. The discovery of mutations in the epidermal growth factor receptor (EGFR) and chromosomal translocations in the anaplastic lymphoma kinase (ALK) have transformed the care of NSCLC by incorporating tumour genotyping in the therapeutic treatment (Tamura et al, 2008; Mok et al, 2009; Solomon et al, 2014). Firstline targeted therapies, as well as platinum-based third-generation antitumour agents, have significantly improved the survival of patients with advanced NSCLC (Mok et al, 2009; Solomon et al, 2014; Sacher et al, 2015). Docetaxel, pemetrexed, and checkpoint blockade blockers are considered standard second-line therapies based on several randomised controlled trials (Shepherd et al, 2000; Hanna et al, 2004; Tassinari et al, 2010; Borghaei et al, 2015). There is no accepted choice for third-line therapy, although erlotinib has been considered. However, for the EGFR unselected or EGFR wild-type patients, the efficacy of thirdline erlotinib is unsatisfactory (Yoshioka et al, 2010), so new therapies are clearly needed.

Anlotinib (AL3818) is an inhibitor targeting multiple receptor tyrosine kinases involved in tumour progression, especially the vascular endothelial growth factor receptor type 2 and 3 , the platelet-derived growth factor $\beta$ (PDGFR $\beta)$, and the stem cell-factor receptor (c-Kit). A phase I study has reported that anlotinib was generally well tolerated at a daily oral dose of $12 \mathrm{mg}$ or lower in patients with advanced refractory solid tumours (Sun et al, 2016).

The present study describes a randomised, double-blind, multicentre, phase II study that determined the efficacy and safety of anlotinib as a third-line or beyond therapy for patients with refractory advanced NSCLC.

\section{MATERIALS AND METHODS}

Study design and patients. This randomised, double-blind, phase II study enrolled patients from 13 hospitals in China between September 2013 and May 2014. Eligibility criteria were as follows: a metastatic or recurrent advanced NSCLC confirmed by histology or cytology; a measurable disease; patients who failed at least two kinds of systemic chemotherapy (third line or beyond) or drug intolerance; patients 18-70 years of age; an Eastern Cooperative Oncology Group PS of $0-2$; an estimated survival duration of $>3$ months; an absolute neutrophil count $\geqslant 1.5 \times 10^{9} 1^{-1}$ and a platelet count $\geqslant 100 \times 10^{9} 1^{-1}$; adequate kidney (creatinine clearance $\geqslant 60 \mathrm{ml} \mathrm{min}^{-1}$ ) and liver functions (bilirubin $<1.25 \times$ the upper limit of normal; and an aspartate transaminase and alanine transaminase $\leqslant 2.5 \times$ the upper limit of normal). Exclusion criteria included the following: a small-cell lung cancer (SCLC, including mixed SCLC/NSCLC); a history of haemoptysis; a symptomatic brain metastases or brain metastases controlled for $<2$ months; a central cavity of squamous cell lung cancer or NSCLC accompanied by haemoptysis ( $>50 \mathrm{ml}$ per day); and a systemic antitumour therapy scheduled in the preceding 4 weeks or during this study.

The study was performed in full accordance with the International Conference of Harmonisation Good Clinical Practice guidelines, the Declaration of Helsinki, and other applicable bioethical guidelines. The study protocol was independently approved by the ethics committees of each participating centre. All patients provided a written informed consent. The trial is registered with Clinicaltrials.gov.

Randomisation and intervention. Patients were registered in an online randomised trial system and medication ordering system. Randomisation was performed centrally and was comparable

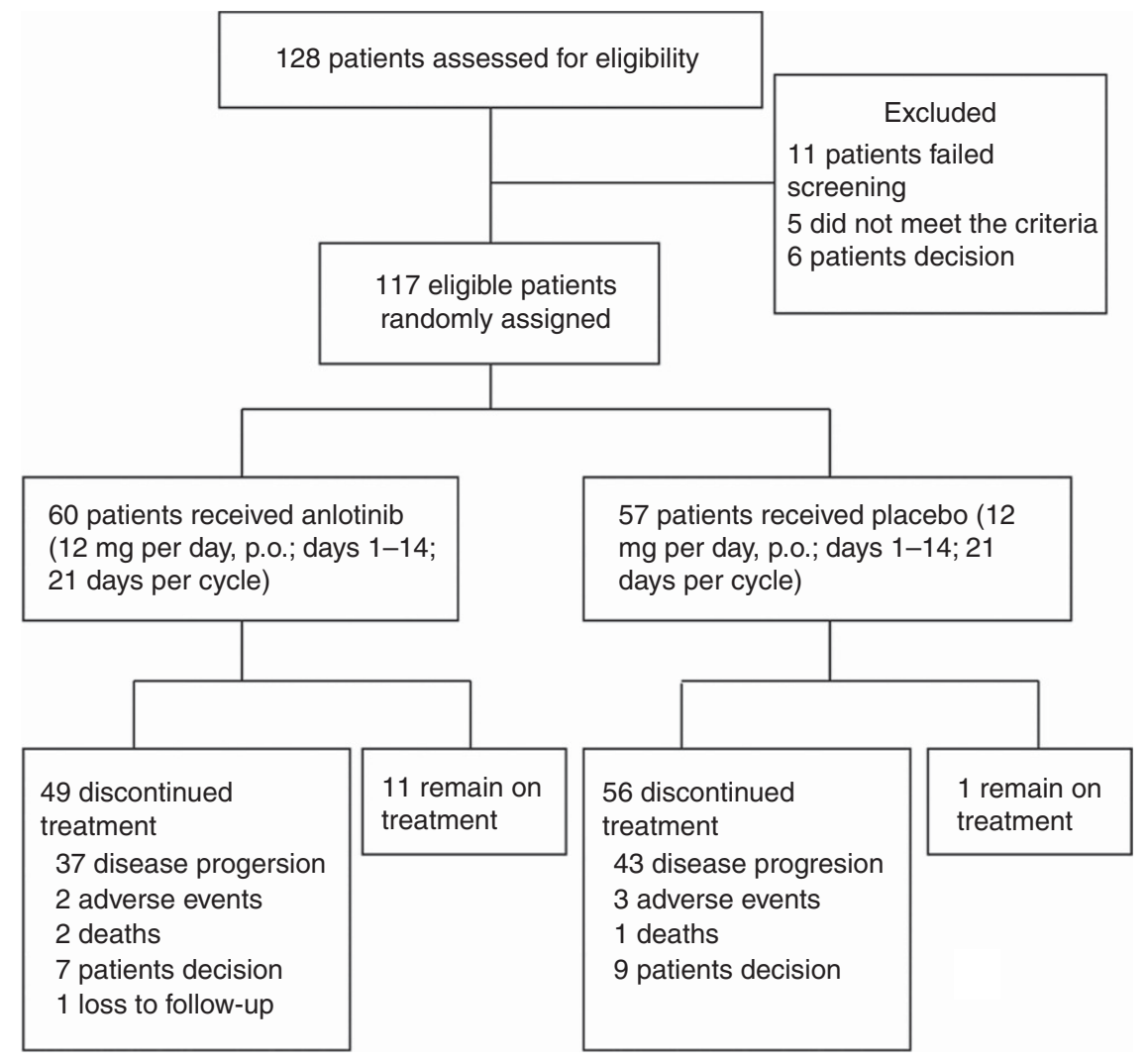

Figure 1. Patient flowchart. 
between the centres. Patients were randomised 1:1 to receive anlotinib (Chia Tai Tianqing Pharmaceutical Group Co., Ltd, Nanjing, China) or placebo (Chia Tai Tianqing Pharmaceutical Group Co., Ltd) until progression, unacceptable toxicity, withdrawal of patient consent, or death. Anlotinib was given orally, once daily $(12 \mathrm{mg})$ on days $1-14$ of a 21 -day cycle. The patients and physicians were blinded to the treatments. Only the pharmacists were aware of the treatments being received, and they had no contact with the patients. The code could be broken anytime for a specific patient in cases of medical emergency.

End points. The primary end point was progression-free survival (PFS) of the intent-to-treat population. PFS was defined as the interval from the date of randomisation to the date of disease progression or death from any cause, whichever occurred first. Secondary end points included the objective response rate (ORR), disease control rate (DCR), and overall survival (OS). The ORR included the complete response (CR) and partial response (PR), and the DCR included the CR, PR, and stable disease (SD). The response to treatment was assessed every two cycles by imaging. Tumour response and progression were assessed according to the Response Evaluation Criteria in Solid Tumours, version 1.1. The OS was defined as the time from randomisation to the date of death or the last follow-up.

Safety was evaluated throughout the study. Adverse events (AEs) were graded according to the NCI Common Terminology Criteria for AEs (CTCAE), version 4.0. The dose could be reduced to $8-10 \mathrm{mg}$ per day for patients who had grade 3 or 4 treatmentrelated toxicities or for patients with intolerable grade 2 toxicity, despite maximum supportive care measures. Adverse events were defined as any adverse medical events occurring after the first dose of the study drug (anlotinib or placebo) in the clinical trial to within 1 month after the last dose. The end points and safety were assessed by an independent review committee comprised of experienced and trained medical and oncological professionals.

Statistical analysis. Using $\alpha=0.05$, a power of $80 \%$, a randomisation ratio of $1: 1$, and a loss to follow-up of $10 \%$, and based on an estimated median PFS of 6 weeks in the placebo group and 12 weeks in the anlotinib group (Paz-Ares et al, 2015), the minimal sample size was estimated to be 48 patients per group.

Efficacy outcomes were analysed based on the intent-to-treat population, which was defined as all randomised subjects. The safety set included all randomised patients who received at least one dose of study medication and had records of safety. Demographic data, outcome data, and other clinical parameters were presented as the frequency for categorical variables, and the mean \pm standard deviation for continuous variables. Proportions were compared using the $\chi^{2}$ test or Fisher's exact test, as appropriate. Continuous variables were tested using an independent-samples $t$-test. The Kaplan--Meier method was used to assess median PFS and OS with 95\% confidence intervals (CIs). Differences in survival were assessed using the log-rank test. The proportional hazards (Cox) model was used to estimate hazard ratios (HRs) for PFS and OS with 95\% CIs. Overall response rates were compared using the Mantel-Haenszel $\chi^{2}$ test. Two-sided values of $P<0.05$ were considered statistically significant.

\section{RESULTS}

Patient population. One hundred and seventeen patients were enrolled from 13 centres between 3 September 2013 and 8 May 2014. Sixty patients were in the anlotinib group and 57 patients were in the placebo group (Figure 1). Baseline characteristics were similar between the two groups (Table 1).
Table 1. Baseline characteristics of the patients ${ }^{a}$

\begin{tabular}{|c|c|c|}
\hline Characteristic & $\begin{array}{c}\text { Anlotinib, } \\
N=60\end{array}$ & $\begin{array}{c}\text { Placebo, } \\
\mathbf{N}=\mathbf{5 7}\end{array}$ \\
\hline Mean age (years) & $55.2 \pm 10.0$ & $55.5 \pm 9.1$ \\
\hline $\begin{array}{l}\text { Age (years), } n(\%) \\
\quad \leqslant 60 \\
>60\end{array}$ & $\begin{array}{l}38(63.3 \%) \\
22(36.7 \%)\end{array}$ & $\begin{array}{l}39(68.4 \%) \\
18(31.6 \%)\end{array}$ \\
\hline $\begin{array}{l}\text { Gender, } n(\%) \\
\quad \text { Male } \\
\text { Female }\end{array}$ & $\begin{array}{l}26(43.3 \%) \\
34(56.7 \%)\end{array}$ & $\begin{array}{l}33 \text { (57.9\%) } \\
24(42.1 \%)\end{array}$ \\
\hline $\begin{array}{l}\text { Smoking history }{ }^{\mathbf{b}}, n(\%) \\
\text { Never } \\
\text { Current/former }\end{array}$ & $\begin{array}{l}42(70.0 \%) \\
18(30.0 \%)\end{array}$ & $\begin{array}{l}29(50.9 \%) \\
28(49.1 \%)\end{array}$ \\
\hline $\begin{array}{l}\text { ECOG, } n(\%) \\
0 \\
1 \\
2\end{array}$ & $\begin{array}{l}7(11.7 \%) \\
47(78.3 \%) \\
6(10.0 \%)\end{array}$ & $\begin{array}{c}3(5.2 \%) \\
49(86.0 \%) \\
5(8.8 \%)\end{array}$ \\
\hline $\begin{array}{l}\text { Histology, } n(\%) \\
\text { Adenocarcinoma } \\
\text { Squamous }\end{array}$ & $\begin{array}{c}54(90.0 \%) \\
6(10.0 \%)\end{array}$ & $\begin{array}{c}50 \text { (87.7\%) } \\
7 \text { (12.3\%) }\end{array}$ \\
\hline $\begin{array}{l}\text { Anatomic stage, } n(\%) \\
\text { IIIB } \\
\text { IV }\end{array}$ & $\begin{array}{c}6(10.0 \%) \\
54(90.0 \%)\end{array}$ & $\begin{array}{c}2(3.5 \%) \\
55(96.5 \%)\end{array}$ \\
\hline $\begin{array}{l}\text { EGFR mutation, } n(\%) \\
\text { Positive } \\
\text { Negative } \\
\text { Unknown }\end{array}$ & $\begin{array}{l}12(20.0 \%) \\
14(23.3 \%) \\
34(56.7 \%)\end{array}$ & $\begin{array}{c}9(15.8 \%) \\
11(19.3 \%) \\
37(64.9 \%)\end{array}$ \\
\hline $\begin{array}{l}\text { Number of metastases } \\
\quad \leqslant 3 \\
>3\end{array}$ & $\begin{array}{l}21(35.0 \%) \\
39(65.0 \%)\end{array}$ & $\begin{array}{l}16 \text { (28.1\%) } \\
41 \text { (71.9\%) }\end{array}$ \\
\hline $\begin{array}{l}\text { Efficacy of previous therapy (disease control) } \\
\text { Yes } \\
\text { No }\end{array}$ & $\begin{array}{c}58(96.7 \%) \\
2(3.3 \%)\end{array}$ & $\begin{array}{c}52(91.2 \%) \\
5 \text { (8.8\%) }\end{array}$ \\
\hline $\begin{array}{l}\text { Treatment after anlotinib failure } \\
\text { Chemotherapy } \\
\text { Best supportive care } \\
\text { EGFR-TKI } \\
\text { Antiangiogenesis therapy }\end{array}$ & $\begin{array}{c}11(18.3 \%) \\
44(73.3 \%) \\
29(48.3 \%) \\
7(11.7 \%)\end{array}$ & $\begin{array}{c}9(15.8 \%) \\
45(78.9 \%) \\
33(57.9 \%) \\
4(7.0 \%)\end{array}$ \\
\hline $\begin{array}{l}\text { Chemotherapy } \\
\text { Pemetrexed + platinum } \\
\text { Docetaxel + platinum } \\
\text { Paclitaxel + platinum } \\
\text { Vinorelbine + platinum } \\
\text { Gemcitabine + platinum } \\
\text { Other }\end{array}$ & $\begin{array}{l}13(21.7 \%) \\
32(53.3 \%) \\
22(36.7 \%) \\
14(23.3 \%) \\
24(40.0 \%) \\
25(41.7 \%)\end{array}$ & $\begin{array}{l}13(22.8 \%) \\
30(52.6 \%) \\
24(42.1 \%) \\
11(19.3 \%) \\
25(43.9 \%) \\
29(50.9 \%)\end{array}$ \\
\hline
\end{tabular}

Abbreviations: $\mathrm{ECOG}=$ Eastern Cooperative Oncology Group; EGFR=epidermal growth factor receptor; $n=$ number.

${ }^{a}$ Values are shown as the mean \pm s.d. or $n(\%)$. There were no between-group differences in the baseline characteristics, except for smoking history (two-sided test).

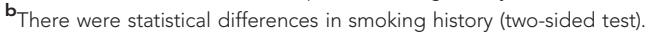

Efficacy. The primary PFS (data cutoff on 31 October 2014) was longer in the anlotinib group (4.8 months; 95\% CI, 3.5-6.4) compared with the placebo group (1.2 months, $95 \%$ CI, $0.7-1.6)$. A Cox model was used to examine the impact of baseline characteristics on PFS, including therapy (anlotibin vs placebo), age, sex, smoking history, stage, the efficacy of previous treatments, histology, and the number of metastases. The results showed that the HR of PFS for the anlotinib group $v s$ the placebo group was 0.32 (95\% CI, 0.20-0.51; $P<0.0001$ ) (Figure 2A). All subgroup analyses showed that the anlotinib group had a significantly longer PFS than the placebo group, except for the $\leqslant 3$ metastases subgroup, especially for patients with $>3$ metastases, and EGFR mutations (Figure 2B). The median PFS for EGFR mutationpositive patients who received anlotinib $(n=12)$ and placebo $(n=9)$ were 6.93 and 0.72 months, respectively $(P<0.001)$. The median PFS for EGFR mutation-negative patients who received 


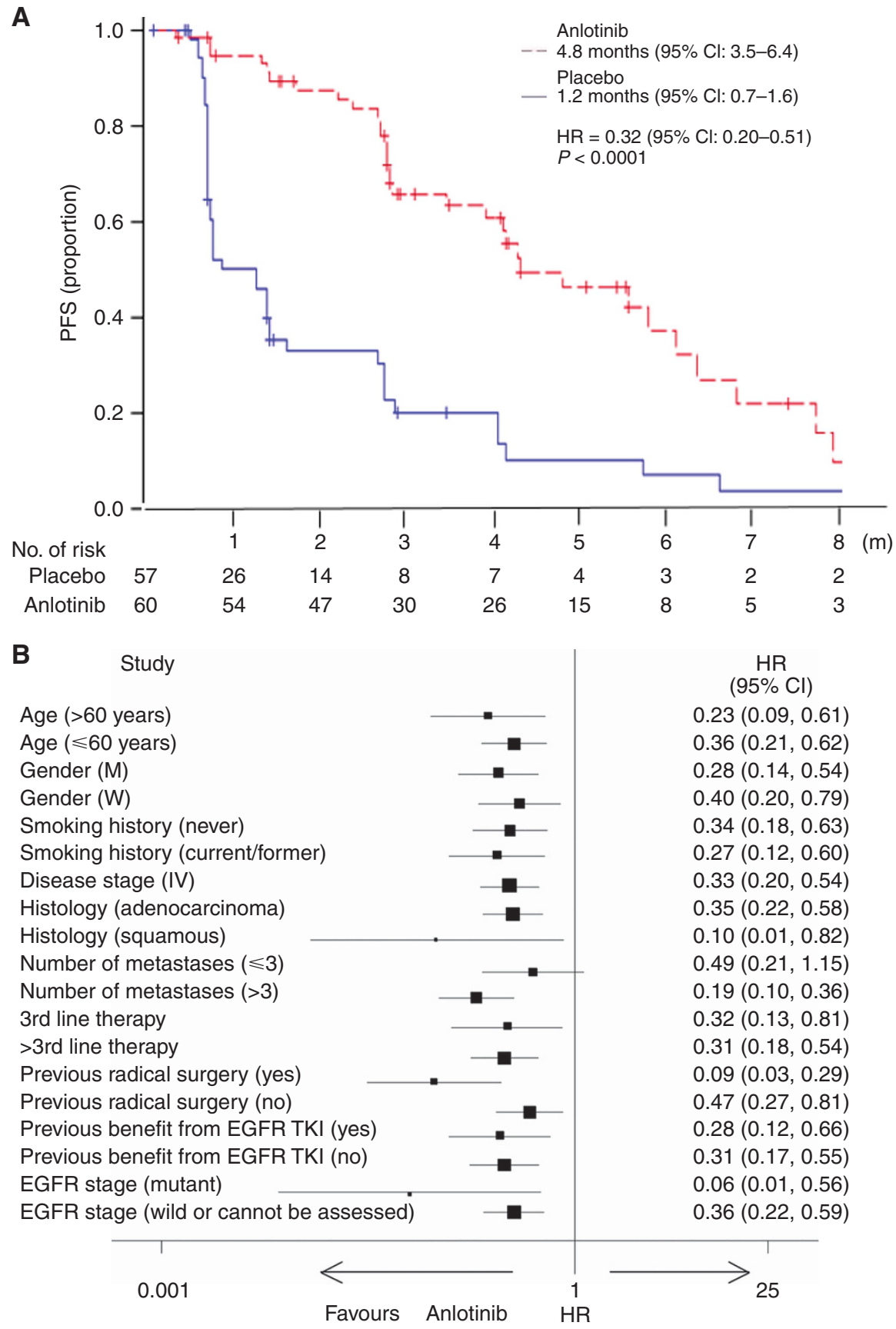

Figure 2. Comparison of progression-free survival. (A) Kaplan-Meier curves of PFS. (B) A Forest plot of PFS in the subgroups. Cl=confidence interval; EGFR=epidermal growth factor receptor; $H R=$ hazard ratio; PFS=progression-free survival.

anlotinib $(n=14)$ and placebo $(n=11)$ were 4.14 and 1.38 months, respectively $(P=0.0022)$. The PFS for the anlotinib group and the placebo group according to different EGFR mutation status were shown in Supplementary Figure 1.

The median OS (data cutoff, 3 February 2016) was 9.3 months (95\% CI, 6.8-15.1) for the anlotinib group, and 6.3 months $(95 \%$ $\mathrm{CI}, 4.3-10.5)$ for the placebo group $(\mathrm{HR}=0.78 ; 95 \% \mathrm{CI}, 0.51-1.18$; $P=0.2316$ ) (Figure 3 ). The median OS for EGFR mutationpositive patients who received anlotinib $(n=12)$ and placebo $(n=9)$ were 7.43 and 4.60 months, respectively $(P=0.9068)$. The median OS for EGFR mutation-negative patients who received anlotinib $(n=14)$ and placebo $(n=11)$ were 10.08 and 5.06 months respectively $(P=0.0187)$ (Supplementary Figure 2$)$. The ORR improved (10.0\%; 95\% CI, 2.4-17.6\% vs 0\%; 95\% CI, 0-6.3\%; $P=0.028$ ) (Table 2). The DCR was $83.3 \%$ (95\% CI, 73.9-92.8\%) in the anlotinib group vs $31.6 \%$ (95\% CI, 19.5-43.7\%) in the placebo group $(P<0.0001)$. Supplementary Figure 3 shows the best percentage change from baseline for the size of the target lesion for patients with measurable disease.

In the anlotinib group, 11 patients (18.3\%) accepted chemotherapy or targeted therapy, and 44 patients $(73.3 \%)$ received the best supportive care after failure of the anlotinib therapy. In the placebo group, nine patients received chemotherapy (15.8\%) and 45 patients $(78.9 \%)$ received the best supportive care after progression. There was no difference between the two groups $(P=0.852)$.

Safety. Adverse events (grades 1-4) occurred more frequently with anlotinib $(91.67 \%$; 55 out of 60$)$ than with placebo $(70.18 \%$; 40 out of 57$)(P=0.0040)$. The following AEs were significantly more frequent in the anlotinib group than in the control group: 


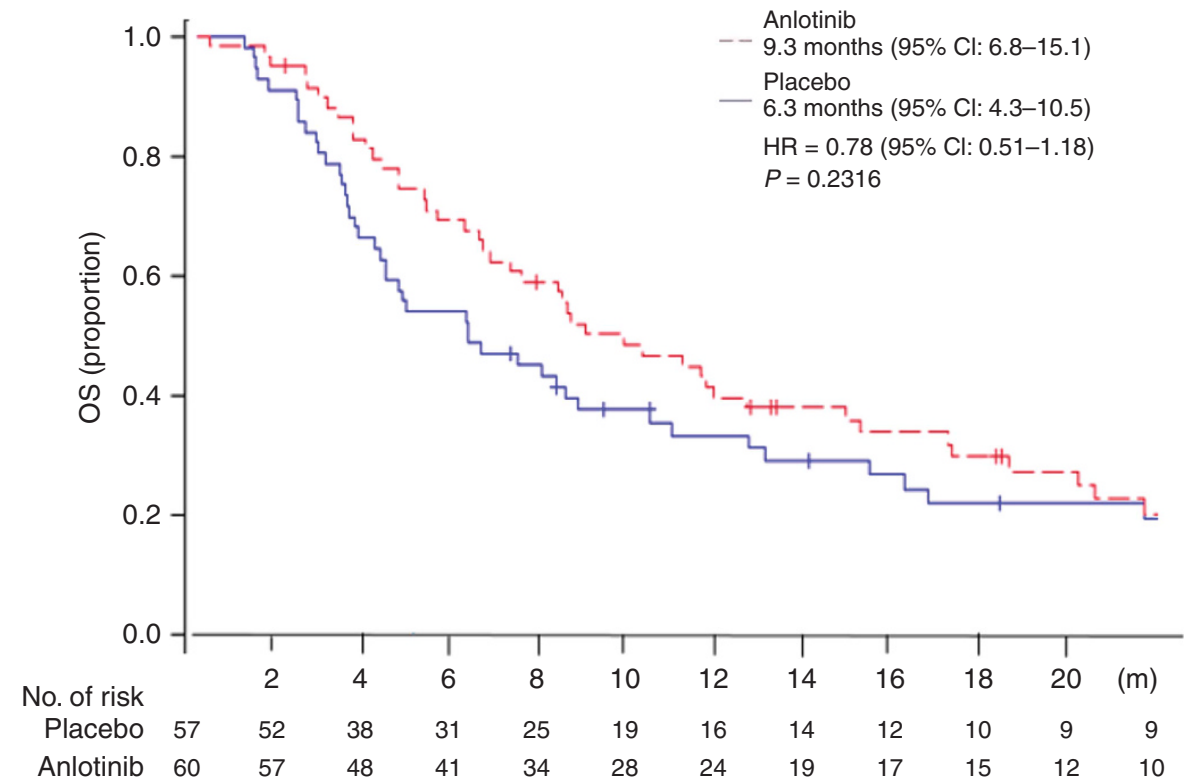

Figure 3. Kaplan-Meier curves of OS. $\mathrm{Cl}=$ confidence interval; $\mathrm{HR}=$ hazard ratio; $\mathrm{OS}=$ overall survival.

Table 2. Overall response percentages in the intent-to-treat set

\begin{tabular}{|l|c|c|}
\hline $\mathbf{n}(\%)$ & Anlotinib, $\mathbf{N}=\mathbf{6 0}$ & Placebo, $\mathbf{N}=\mathbf{5 7}$ \\
\hline ORR $^{\mathbf{a}}$ & $6(10.0 \%)$ & $0(0.0 \%)$ \\
\hline Complete response & $0(0.0 \%)$ & $0(0.0 \%)$ \\
\hline Partial response & $6(10.0 \%)$ & $0(0.0 \%)$ \\
\hline Stable disease & $44(73.3 \%)$ & $18(31.6 \%)$ \\
\hline Progressive disease & $5(8.3 \%)$ & $32(56.1 \%)$ \\
\hline Unevaluable & $5(8.3 \%)$ & $7(12.3 \%)$ \\
\hline $\begin{array}{l}\text { Abbreviations: DCR = disease control rate; } n=\text { number; ORR = overall response rate. } \\
\text { a There was a statistical difference between the two groups (two-sided test). } P=0.0276 \text { for } \\
\text { the ORR; } P<0.0001 \text { for the DCR. }\end{array}$ \\
\hline
\end{tabular}

hypertension (55.00\%), elevated thyroid-stimulating hormone (TSH, 36.67\%), hand and foot syndrome (HFSR, 28.33\%), elevated thyroglobulin (TG, 26.67\%), elevated total cholesterol $(25.00 \%)$, and diarrhoea $(23.33 \%)$. The percentage of treatment-related grade 3 or 4 AEs in the anlotinib group was $21.67 \%$ (13 out of 60 ) compared with $5.26 \%$ (3 out of 57) in the placebo group $(P=0.0140)$. The most common treatment-related grade 3 or 4 AEs in the anlotinib group were hypertension (10.00\%), elevated TG (5.00\%), and HFSR (3.33\%) (Table 3). All AEs observed during the trial were controlled after dose reduction or symptomatic treatments. All patients in the anlotinib group began treatment at $12 \mathrm{mg}$ per day. Six patients had a dose reduction to $10 \mathrm{mg}$ per day (four for hypertension and HFSR, one for a slight elevation of liver enzymes, and one for stomatitis). There was no dose adjustment in the placebo group. There was no treatment-related death.

\section{DISCUSSION}

This study assessed the safety and efficacy of anlotinib as a thirdline treatment or beyond for patients with refractory advanced NSCLC. The results showed that the PFS, as well as the ORR and DCR, were better with anlotinib compared with the placebo. Anlotinib therapy had a prolonged OS of 3 months, but failed to reach statistical significance $(\mathrm{HR}=0.78 ; 95 \% \mathrm{CI}, 0.51-1.18)$.

Angiogensis is considered a hallmark of malignancies such as lung cancer, as it is an integral part of tumour growth, progression, and metastasis. Proangiogenic pathways are attractive therapeutic targets because they are commonly overexpressed in NSCLC. The VEGF pathway is the most recognised proangiogenic pathway, and other proangiogenic pathways include PDGF and FGF (Al Farsi and Ellis, 2015). Multitarget tyrosine kinase inhibitors that disrupt these pathways could decrease tumour proliferation. In a phase I study that evaluated anlotinib in patients with solid tumours, $>60 \%$ of patients who received $12 \mathrm{mg}$ once daily had tumour burden shrinkage (Sun et al, 2016). Similar results were confirmed in the present study, with $70 \%$ of the patients in the anlotinib group showing tumour burden shrinkage (Supplementary Figure 1).

A notable feature of this study was that it was designed to evaluate the efficacy of anlotinib as a third-line or beyond treatment for NSCLC; the results showed that this treatment benefited PFS. Current treatments for advanced NSCLC are still inadequate, and patients who fail second-line treatments require additional treatments that are usually based on each physician's experience. Although EGFR TKIs have been suggested as a thirdline therapy for advanced NSCLC patients who have not received erlotinib or gefitinib and have a PS of 0-3, the efficacy of this treatment was limited (Masters et al, 2015). In the DELTA study, for the EGFR unselected population, second- or third-line EGFR TKI therapy only provided a PFS of 2.0 months (Kawaguchi et al, 2014). Phase II of erlotinib alone as a third-line therapy showed a median PFS of 2.1 months (Matsuura et al, 2011). Present clinical results are insufficient to recommend routine third-line cytotoxic chemotherapy. A prospective single-arm trial of S-1 as a third-line treatment in patients with NSCLC showed a median PFS of 71 days (Miyoshi et al, 2014). A retrospective study only demonstrated an ORR of $2.3 \%$ and a DCR of $30 \%$ after a third-line cytotoxic treatment (Massarelli et al, 2003). The present study showed that single-agent anlotinib as a third-line or later treatment resulted in an encouraging ORR of $10.0 \%$ and a PFS of 4.8 month, when compared with other therapies for the same population in previous reports.

A previous prospective study (the MISSION study) was used to evaluate a multitarget tyrosine kinase inhibitor (sorafenib) for advanced refractory nonsquamous NSCLC whose disease progressed after two or three previous treatments (Paz-Ares et al, 2015). The results showed a significantly longer PFS in the sorafenib group than the placebo group in the overall study population, and the improvement was consistent among most of 
Table 3. Adverse events, regardless of causality, reported in $\geq 10 \%$ of patients in the anlotinib group

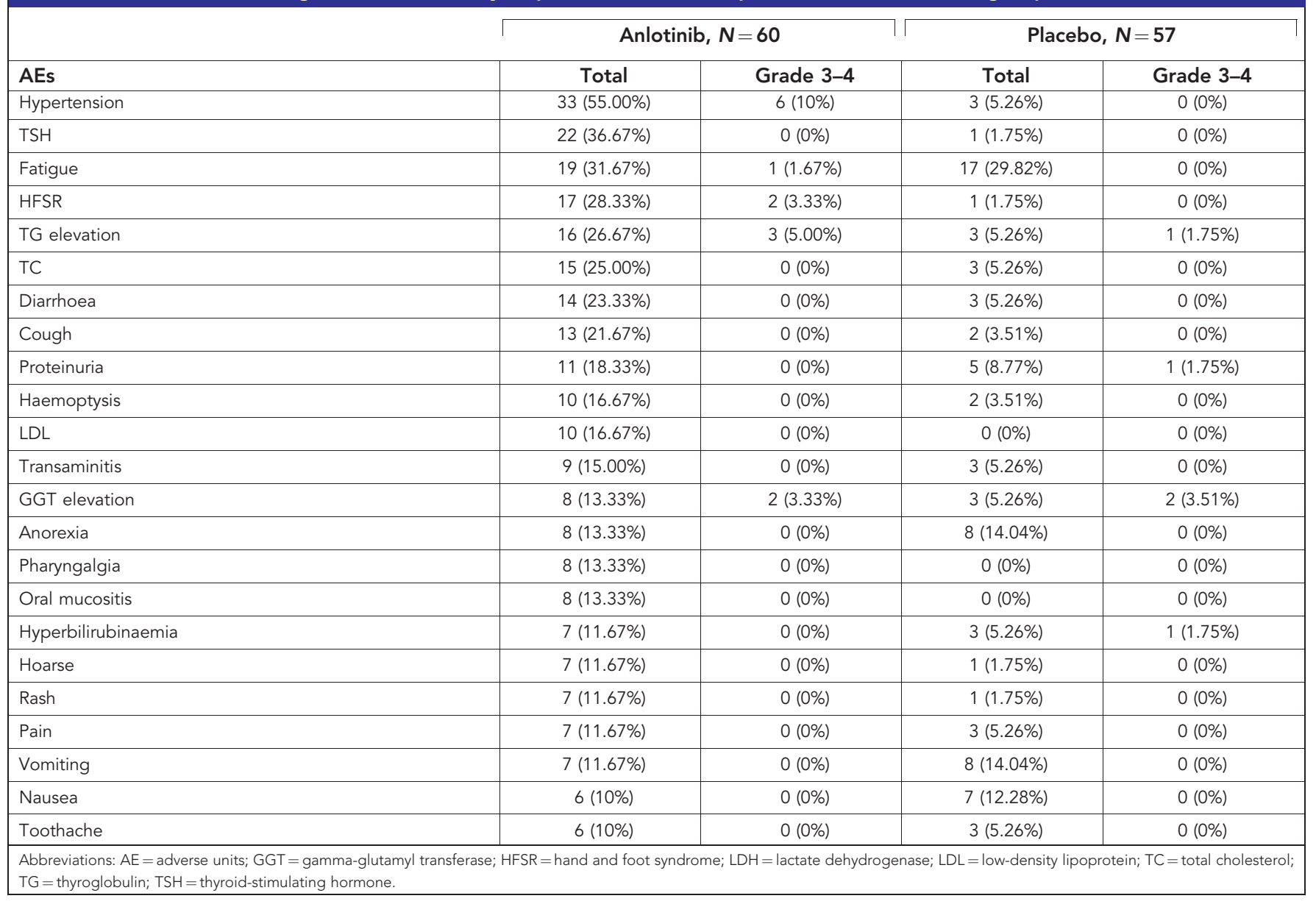

the analysed subgroups. Similarly, in the current study, all subgroup analyses showed that the anlotinib group had a significantly longer PFS than the placebo group, except for the $\leqslant 3$ metastases subgroup. This result suggested that the PFS benefit might be better correlated with tumours involving multiple metastases. Metastasis is a very complex biological process in carcinomas that mainly relies on the invasion and migration abilities of the malignant tumour cells, which need more oxygen and nutrients to sustain biosynthetic processes (Song et al, 2012). In this setting, the tumours of rapid progression would be more likely to be dependent on new blood vessels, and should contain a higher percentage of immature, growth factor-dependent vessels (Ogino et al, 2008). Shou et al (2001) reported that overexpression of VEGF was independent characteristic affecting the pT factor and lymphatic permeation in primary lung cancer, and they have found a significant correlation between VEGF expression and poor prognosis in NSCLC. This might explain superior efficacy of anlotinib in $>3$ metastases subgroup in the present study. Similarly, subgroup analyses in the LUME-Lung 1 study, which evaluated additional nintedanib as a second-line therapy for NSCLC, reported that the OS benefits were correlated with patients with rapidly progressing tumours (Reck et al, 2014).

The OS was 9.3 months in the anlotinib group, which was longer than the 6.3 months in the placebo group, although the difference was close but not significant $(P=0.2316)$. The small sample size could account for the failure of statistical significance. The post study treatments of the two groups in the present study were balanced in the total study population $(P=0.852)$. In the anlotinib group, 11 patients $(18.3 \%)$ received chemotherapy or targeted therapy, and in the placebo group, nine patients received chemotherapy (15.8\%). We therefore suggest that the modest OS advantage in the anlotinib group was attributable to the treatment effect of anlotinib therapy, and not to post-study treatments.

With the development of cancer treatment strategies, especially in those have been proven the survival benefit, such as thirdgeneration targeted therapy and immune checkpoint inhibitors, multiline therapy may become a reasonable and common choice to control disease progression for most advanced NSCLC patients. At present, immune checkpoint inhibitors were recommended for both first-line and subsequent therapy. Recently, NCCN guideline suggested that PD-1 and PD-L1 inhibitor such as nivolumab, pembrolizumab, and atezolizumab could be potential options for the patients progressed after two lines of targeted and/or chemotherapies (Ettinger et al, 2017). According to several trials for the second- and further-line treatments, immunotherapy showed 9.2 to 12.7 months in median OS (Brahmer et al, 2015; Fehrenbacher et al, 2016; Herbst et al, 2016), which is similar to anlotinib phase II trial. Therefore, the efficacy of anlotinib also showed its feasibility to be a potential option as third-line therapy in NSCLC, in particular, for those patients without or have lower expression of PD-L1. Based on these promising results of the phase II study, we are conducting a phase III trial to validate the efficacy of anlotinib in patients who previously have failed or intolerance to at least two systemic therapies. All participants in phase III trial must perform gene mutation test including EGFR or ALK in tumour tissues by using NGS sequencing or fluorescence in situ hybridisation. In addition, the exploration of the biomarker to evaluate the efficacy of anlotinib will also be involved.

In this phase II study, there was no treatment-related death. The most common AEs were hypertension, elevated TSH, and HFSR. 
These AEs are similar to those described for other TKIs (Paz-Ares et al, 2015; Reck et al, 2015). The present study is the first to report the efficacy of anlotinib treatment in NSCLC, although direct comparisons of AEs with other studies involving this drug are currently not possible.

The present study had some limitations. The drug was only compared with a placebo, and additional studies are necessary to compare it directly with other approved treatments, such as EGFR TKI. In addition, the characteristics of patients were not analysed to determine which patients benefited more from anlotinib treatment. In the future, a phase III randomised control trial is necessary to address this point.

In conclusion, anlotinib as third- or further-line treatment is well tolerated and offers significantly prolonged PFS in patients with advanced NSCLC when compared with placebo.

\section{ACKNOWLEDGEMENTS}

This study was funded by Chia Tai Tianqing Pharmaceutical Group Co., Ltd, Nanjing, Jiangsu Province, China. We acknowledge the invaluable participation of the patients.

\section{CONFLICT OF INTEREST}

$\mathrm{BH}$ has consulted for AstraZeneca, Roche Pharmaceutical Company. He also received payment for speaking from AstraZeneca Pharmaceutical Company and Lily Pharmaceutical Company. All remaining authors have declared no conflicts of interest.

\section{REFERENCES}

Al Farsi A, Ellis PM (2015) Anti-angiogenic therapy in advanced non-small cell lung carcinoma (NSCLC): is there a role in subsequent lines of therapy? J Thorac Dis 7(3): 214-216.

Borghaei H, Paz-Ares L, Horn L, Spigel DR, Steins M, Ready NE, Chow LQ, Vokes EE, Felip E, Holgado E, Barlesi F, Kohlhäufl M, Arrieta O, Burgio MA, Fayette J, Lena H, Poddubskaya E, Gerber DE, Gettinger SN, Rudin CM, Rizvi N, Crinò L, Blumenschein Jr GR, Antonia SJ, Dorange C, Harbison CT, Graf Finckenstein F, Brahmer JR (2015) Nivolumab versus docetaxel in advanced nonsquamous non-small-cell lung cancer. $N$ Engl $J$ Med 373(17): 1627-1639.

Brahmer J, Reckamp KL, Baas P, Crinò L, Eberhardt WE, Poddubskaya E, Antonia S, Pluzanski A, Vokes EE, Holgado E, Waterhouse D, Ready N, Gainor J, Arén Frontera O, Havel L, Steins M, Garassino MC, Aerts JG, Domine M, Paz-Ares L, Reck M, Baudelet C, Harbison CT, Lestini B, Spigel DR (2015) Nivolumab versus docetaxel in advanced squamous-cell non-small-cell lung cancer. N Engl J Med 373(2): 123-135.

Ettinger DS, Wood DE, Aisner DL, Akerley W, Bauman J, Chirieac LR, D’Amico TA, DeCamp MM, Dilling TJ, Dobelbower M, Doebele RC, Govindan R, Gubens MA, Hennon M, Horn L, Komaki R, Lackner RP, Lanuti M, Leal TA, Leisch LJ, Lilenbaum R, Lin J, Loo Jr BW, Martins R, Otterson GA, Reckamp K, Riely GJ, Schild SE, Shapiro TA, Stevenson J, Swanson SJ, Tauer K, Yang SC, Gregory K, Hughes M (2017) Non-small cell lung cancer, version 5.2017, NCCN Clinical Practice Guidelines in Oncology. J Natl Compr Canc Netw 15(4): 504-535.

Fehrenbacher L, Spira A, Ballinger M, Kowanetz M, Vansteenkiste J, Mazieres J, Park K, Smith D, Artal-Cortes A, Lewanski C, Braiteh F, Waterkamp D, He P, Zou W, Chen DS, Yi J, Sandler A, Rittmeyer A. POPLAR Study Group (2016) Atezolizumab versus docetaxel for patients with previously treated non-small-cell lung cancer (POPLAR): a multicentre, open-label, phase 2 randomised controlled trial. Lancet 387(10030): 1837-1846.

Hanna N, Shepherd FA, Fossella FV, Pereira JR, De Marinis F, von Pawel J, Gatzemeier U, Tsao TC, Pless M, Muller T, Lim HL, Desch C, Szondy K, Gervais R, Shaharyar, Manegold C, Paul S, Paoletti P, Einhorn L, Bunn Jr PA (2004) Randomized phase III trial of pemetrexed versus docetaxel in patients with non-small-cell lung cancer previously treated with chemotherapy. J Clin Oncol 22(9): 1589-1597.

Herbst RS, Baas P, Kim DW, Felip E, Pérez-Gracia JL, Han JY, Molina J, Kim JH, Arvis CD, Ahn MJ, Majem M, Fidler MJ, de Castro Jr G, Garrido M, Lubiniecki GM, Shentu Y, Im E, Dolled-Filhart M, Garon EB (2016) Pembrolizumab versus docetaxel for previously treated, PD-L1positive, advanced non-small-cell lung cancer (KEYNOTE-010): a randomised controlled trial. Lancet 387(10027): 1540-1550.

Kawaguchi T, Ando M, Asami K, Okano Y, Fukuda M, Nakagawa H, Ibata H, Kozuki T, Endo T, Tamura A, Kamimura M, Sakamoto K, Yoshimi M, Soejima Y, Tomizawa Y, Isa S, Takada M, Saka H, Kubo A (2014) Randomized phase III trial of erlotinib versus docetaxel as second- or third-line therapy in patients with advanced non-small-cell lung cancer: Docetaxel and Erlotinib Lung Cancer Trial (DELTA). J Clin Oncol 32(18): 1902-1908.

Massarelli E, Andre F, Liu DD, Lee JJ, Wolf M, Fandi A, Ochs J, Le Chevalier T, Fossella F, Herbst RS (2003) A retrospective analysis of the outcome of patients who have received two prior chemotherapy regimens including platinum and docetaxel for recurrent non-small-cell lung cancer. Lung Cancer 39(1): 55-61.

Masters GA, Temin S, Azzoli CG, Giaccone G, Baker Jr S, Brahmer JR, Ellis PM, Gajra A, Rackear N, Schiller JH, Smith TJ, Strawn JR, Trent D, Johnson DH (2015) Systemic therapy for stage IV non-small-cell lung cancer: American Society of Clinical Oncology Clinical Practice Guideline Update. J Clin Oncol 33(30): 3488-3515.

Matsuura S, Inui N, Ozawa Y, Nakamura Y, Toyoshima M, Yasuda K, Yamada T, Shirai T, Suganuma H, Yokomura K, Suda T, Chida K (2011) Phase II study of erlotinib as third-line monotherapy in patients with advanced non-small-cell lung cancer without epidermal growth factor receptor mutations. Jpn J Clin Oncol 41(8): 959-963.

Miyoshi S, Ito R, Katayama H, Kadowaki T, Yano S, Watanabe A, Abe M, Hamada H, Okura T, Higaki J (2014) Phase II trial of S-1 as third-line or further chemotherapy in patients with advanced non-small-cell lung cancer. Int J Clin Oncol 19(6): 1005-1010.

Mok TS, Wu YL, Thongprasert S, Yang CH, Chu DT, Saijo N, Sunpaweravong P, Han B, Margono B, Ichinose Y, Nishiwaki Y, Ohe Y, Yang JJ, Chewaskulyong B, Jiang H, Duffield EL, Watkins CL, Armour AA, Fukuoka M (2009) Gefitinib or carboplatin-paclitaxel in pulmonary adenocarcinoma. $N$ Engl J Med 361(10): 947-957.

Molina JR, Yang P, Cassivi SD, Schild SE, Adjei AA (2008) Non-small cell lung cancer: epidemiology, risk factors, treatment, and survivorship. Mayo Clin Proc 83(5): 584-594.

Ogino H, Yano S, Kakiuchi S, Muguruma H, Ikuta K, Hanibuchi M, Uehara H, Tsuchida K, Sugino H, Sone S (2008) Follistatin suppresses the production of experimental multiple-organ metastasis by small cell lung cancer cells in natural killer cell-depleted SCID mice. Clin Cancer Res 14(3): 660-667.

Paz-Ares L, Hirsh V, Zhang L, de Marinis F, Yang JC, Wakelee HA, Seto T, Wu YL, Novello S, Juhász E, Arén O, Sun Y, Schmelter T, Ong TJ, Peña C, Smit EF, Mok TS (2015) Monotherapy Administration of Sorafenib in Patients With Non-Small Cell Lung Cancer (MISSION) Trial: a phase III, multicenter, placebo-controlled trial of sorafenib in patients with relapsed or refractory predominantly nonsquamous non-small-cell lung cancer after 2 or 3 previous treatment regimens. J Thorac Oncol 10(12): $1745-1753$.

Reck M, Kaiser R, Mellemgaard A, Douillard JY, Orlov S, Krzakowski M, von Pawel J, Gottfried M, Bondarenko I, Liao M, Gann CN, Barrueco J, Gaschler-Markefski B, Novello S (2014) Docetaxel plus nintedanib versus docetaxel plus placebo in patients with previously treated non-small-cell lung cancer (LUME-Lung 1): a phase 3, double-blind, randomised controlled trial. Lancet Oncol 15(2): 143-155.

Reck M, Mellemgaard A, von Pawel J, Gottfried M, Bondarenko I, Cheng Y, Zarogoulidis K, Luft A, Bennouna J, Barrueco J, Aboshady H, Hocke J, Kaiser R, Douillard JY (2015) Anti-angiogenic-specific adverse events in patients with non-small cell lung cancer treated with nintedanib and docetaxel. Lung Cancer 90(2): 267-273.

Sacher AG, Le LW, Lau A, Earle CC, Leighl NB (2015) Real-world chemotherapy treatment patterns in metastatic non-small cell lung cancer: are patients undertreated? Cancer 121(15): 2562-2569.

Shepherd FA, Dancey J, Ramlau R, Mattson K, Gralla R, O’Rourke M, Levitan N, Gressot L, Vincent M, Burkes R, Coughlin S, Kim Y, Berille J (2000) Prospective randomized trial of docetaxel versus best supportive 
care in patients with non-small-cell lung cancer previously treated with platinum-based chemotherapy. J Clin Oncol 18(10): 2095-2103.

Shou Y, Hirano T, Gong Y, Kato Y, Yoshida K, Ohira T, Ikeda N, Konaka C, Ebihara Y, Zhao F, Kato H (2001) Influence of angiogenetic factors and matrix metalloproteinases upon tumour progression in non-small-cell lung cancer. Br J Cancer 85(11): 1706-1712.

Solomon BJ, Mok T, Kim DW, Wu YL, Nakagawa K, Mekhail T, Felip E, Cappuzzo F, Paolini J, Usari T, Iyer S, Reisman A, Wilner KD, Tursi J, Blackhall F (2014) First-line crizotinib versus chemotherapy in ALKpositive lung cancer. $N$ Engl J Med 371(23): 2167-2177.

Song Y, Xue L, Du S, Sun M, Hu J, Hao L, Gong L, Yeh D, Xiong H, Shao S (2012) Caveolin-1 knockdown is associated with the metastasis and proliferation of human lung cancer cell line NCI-H460. Biomed Pharmacother 66(6): 439-447.

Sun Y, Niu W, Du F, Du C, Li S, Wang J, Li L, Wang F, Hao Y, Li C, Chi Y (2016) Safety, pharmacokinetics, and antitumor properties of anlotinib, an oral multi-target tyrosine kinase inhibitor, in patients with advanced refractory solid tumors. J Hematol Oncol 9(1): 105-113.

Tamura K, Okamoto I, Kashii T, Negoro S, Hirashima T, Kudoh S, Ichinose Y, Ebi N, Shibata K, Nishimura T, Katakami N, Sawa T, Shimizu E, Fukuoka J, Satoh T, Fukuoka M (2008) Multicentre prospective phase II trial of gefitinib for advanced non-small cell lung cancer with epidermal growth factor receptor mutations: results of the West Japan Thoracic Oncology Group trial (WJTOG0403). Br J Cancer 98(5): 907-914.

Tassinari D, Drudi F, Lazzari-Agli L, Tombesi P, Sartori S (2010) Second-line treatments of advanced non-small-cell lung cancer: new evidence for clinical practice. Ann Oncol 21(2): 428-429.

Torre LA, Bray F, Siegel RL, Ferlay J, Lortet-Tieulent J, Jemal A (2015) Global Cancer Statistics, 2012. CA Cancer J Clin 65(2): 87-108.

Yoshioka H, Hotta K, Kiura K, Takigawa N, Hayashi H, Harita S, Kuyama S, Segawa Y, Kamei H, Umemura S, Bessho A, Tabata M, Tanimoto M (2010) A phase II trial of erlotinib monotherapy in pretreated patients with advanced non-small cell lung cancer who do not possess active EGFR mutations: Okayama Lung Cancer Study Group Trial 0705. J Thorac Oncol 5(1): 99-104.

This work is published under the standard license to publish agreement. After 12 months the work will become freely available and the license terms will switch to a Creative Commons AttributionNonCommercial-Share Alike 4.0 Unported License.

Supplementary Information accompanies this paper on British Journal of Cancer website (http://www.nature.com/bjc) 